\title{
Estimation of energy potential and power generation from tidal basin in coastal area of malaysia
}

\author{
Nazani Nazri ${ }^{1, a}$, Shahrani Anuar ${ }^{1}$, Firdaus Basrawi ${ }^{1}$, Ahmmad Shukrie $^{1}$, Siti Aishah $^{1}$ \\ ${ }^{1}$ Energy Sustainable Focus Group (ESFG), 26600 Pekan, Malaysia
}

\begin{abstract}
This paper presents the potential of tidal energy in Malaysia. Malaysia is heavily depending on the fossil fuel to satisfy the energy demand. However, this reserve energy is reported will be depleted. The population growth also caused the demand on energy increase over the year. This situation can lead to the global warming and climate change that be a major concern around the world. As an alternative, renewable energy become a solution in order to reduce the usage of conventional energy such as fossil fuel, coal and gas. One of the renewable energy that can be used is from ocean energy. Since the tidal energy is not study thoroughly in Malaysia and Malaysia has a potential sites that can implement this tidal energy for electricity generation to meet the local demand. This tidal energy can be harnessed in several approach such as by using tidal barrage single basin with single mode generation consist ebb-mode and flood-mode of generation and the other approach of single mode is double-mode of generation. In order to meet the local demand, single-mode generation and double-mode generation was studied by getting the number of population at that area, the electricity demand then from that data the basin area is estimated for power generation. The result shows that double-mode generation is one of the approaches that meet the local demand for electricity.
\end{abstract}

\section{Introduction}

Malaysia is heavily depending on the fossil fuel to satisfy the energy requirements and it is increasingly over the year. However, it is reported that Malaysia oil reserve will be depleted by year 2015 and gas by year 2048 [1]. As a developing country, Malaysia's population increase over the year with an annual growth rate of $1.8 \%$ and it is expected will reach 33.4 million by the year 2020 and approximately 37.4 million in 2030 [2]. In 2013, total electrical generated was $131.6 \mathrm{TWh}$ and the demand is expected to increase by $5.7 \%$ per annum to $274 \mathrm{TWh}$ by year 2030 [3]. This is heavily influenced by strong demand from industrial and residential sector as Malaysia enter the industrialized nation, whereby per capita electricity demand is expected to reach $7571 \mathrm{kWh} /$ person during 2030 [4]. It is difficult to ignore the global warming and the effect of the fossil fuel and nowadays, it becomes as one of the major concern around the world. The limitation of fossil fuel, push the government to find other sources of energy and started to explore the usage of renewable energy $[5,6]$.

The oceans have tremendous untapped natural sources, which are able to make significant contribution to our future energy demand. Besides, the oceans is already known as one the potential renewable sources that can generate electricity by using several technology such as tidal barrage, tidal current energy, wave energy, ocean thermal energy and salinity gradient energy [7].

\footnotetext{
${ }^{\mathrm{a}}$ Corresponding author: mnazani@gmail.com
}

Researchers faced many obstacles on finding highly applicable and cost effective technologies to develop this kind of sources.

The potential of harnessing energy from the ocean in Malaysia is being investigated since a little effort has been put to initiate such studies. It is identified there are a number of sites with great potential for tidal energy conversion, which could supplement the energy needs of Malaysia as well reduce the greenhouse gas generation [8]. As the tidal cycle is highly predictable, it has the potential to be a very reliable renewable energy source. The approach that being researched to harness electric energy from tides are by using tidal barrage single basin which are consist the ebb-mode, flood-mode and doublemode of generation [9].

The paper presents the findings on the preliminary studies undertaken to identify the potential of harnessing tidal energy in Malaysia for electricity generation. As well, it is aimed to identify the potential sites around coastal area of Malaysia that can implement the tidal power plant in order to meet the local electricity demand.

\section{Local population and energy demand}

The local demand was based on the mukim that the tidal station were located [10]. The average electricity consumption in Malaysia is assumed $3966 \mathrm{kWh}$ per household annually [11]. By using assumed electricity consumption, then amount of electricity demands by local 
population is calculated and shown in the Table 1 . This is important in order to determine the tidal basin area.

Table 1. Local electricity demand

\begin{tabular}{llrr}
\hline Location & \multicolumn{1}{c}{ Mukim } & $\begin{array}{c}\text { No. of } \\
\text { household }\end{array}$ & \multicolumn{1}{c}{$\begin{array}{c}\text { Demand } \\
\text { (GWh) }\end{array}$} \\
\hline P.Langkawi & P.Langkawi & 26,000 & 103.12 \\
P.Pinang & Georgetown & 64,653 & 256.41 \\
Lumut & Lumut & 16,591 & 65.80 \\
P.Kelang & Bandar & 3,447 & 13.67 \\
Tg. Keling & Tg. Keling & 2,991 & 11.86 \\
Kukup & Serkat & 1,976 & 7.84 \\
J.Bahru & Sg. Tiram & 3,703 & 14.69 \\
Sejingkat & Padawan & 6,636 & 26.32 \\
Bintulu & Sebauh & 35,274 & 139.90 \\
Miri & Sibuti & 11,958 & 47.43 \\
K.Kinabalu & Tambunan & 81,747 & 324.21 \\
Kudat & Pitas & 16,745 & 66.41 \\
Sandakan & Tongod & 64,194 & 254.60 \\
Lahad Datu & Kunak & 34,179 & 135.55 \\
Tawau & Nabawan & 69,656 & 276.26 \\
Labuan & W.P.Labuan & 19,719 & 78.21 \\
\hline & & & \\
\hline
\end{tabular}

\section{Tidal barrages}

A tidal barrage is one of the technologies that commonly used worldwide for harnessing the tidal energy for electricity generation. It is a physically barrier, namely the barrage is created within the sea with sluice gate to control the flow of sea water $[12,13]$.

There are divided into three approaches which are ebb-mode, flood-mode and double-mode of generation. For ebb-mode, firstly the sluice gate is opened and let sea water flow through it and fills the basin behind barrage. Once the high tide reach the high level and the basin reach it sufficient head level, the sluice gate will close and wait for the tides recedes. This situation will create a difference in water level between the barrage and the sea. Then the potential energy from the water level difference can then drive the turbine to generate electricity [14].

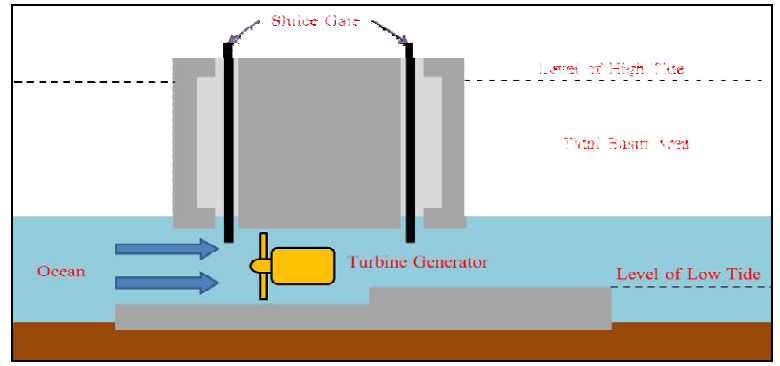

(a)

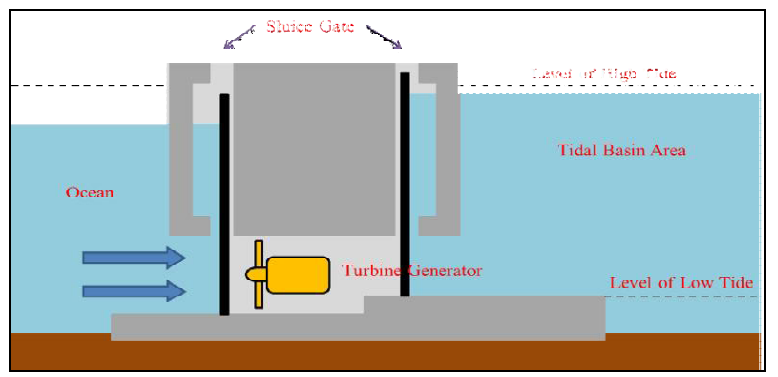

(b)

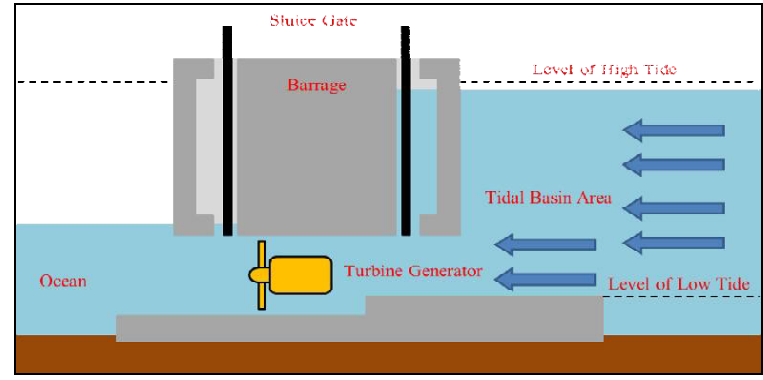

(c)

Figure 1. Ebb-mode generation.

For the flood-mode, sluice gate is closed until the tides reach its high level. After, high level of tides is reached then sluice is opened and let sea water fill the basin through the turbine and in the same time turbine generate the electricity [15]. After the basin is fully filled with sea water and turbine done generate electricity, the sluice gate is closed wait for the sea level decrease. After the sea level is decreased, now the sluice gate is opened once again to empty the basin and water return to the sea through the turbine but it did not generate the electricity because it works only in one direction. This proses repeat during the flood. 


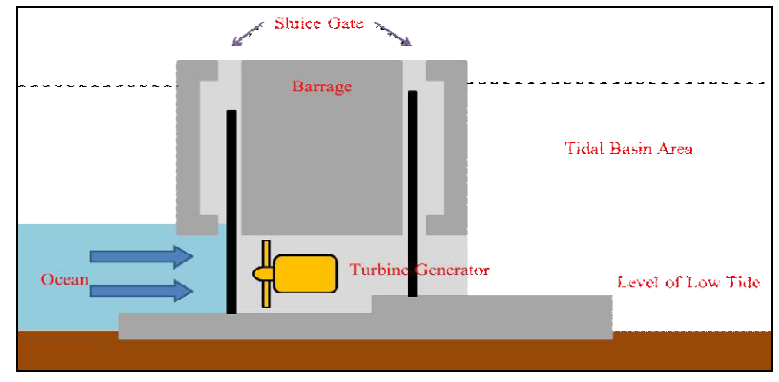

(a)

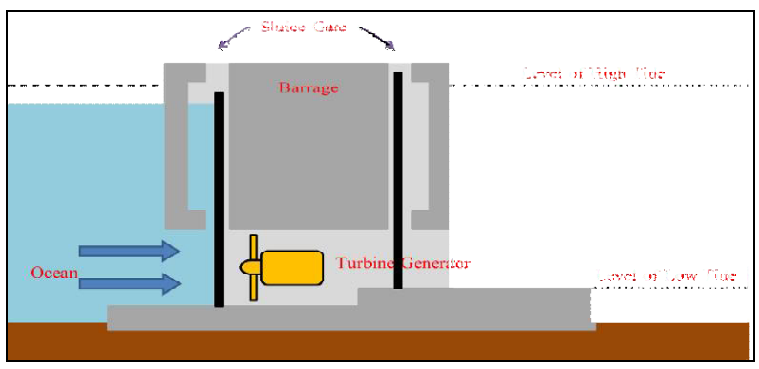

(b)

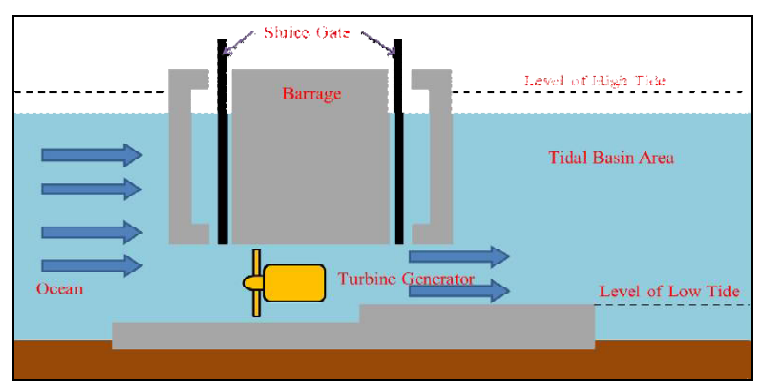

(c)

Figure 2. Flood-mode generation.

While for the double-mode, sluice gate is closed until near the end of the flood tide then water is allowed to flow through the turbine into the basin and creating electricity. At the point where the hydrostatic head is insufficient for power generation the sluice gate is opened and kept opened until high tide when they are closed. When the tide outside the barrage has dropped sufficiently water is allowed to flow out of the basin through the turbine again creating electricity [16].

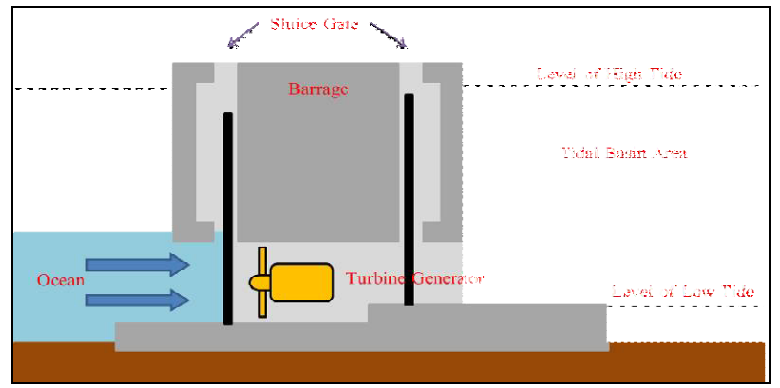

(a)

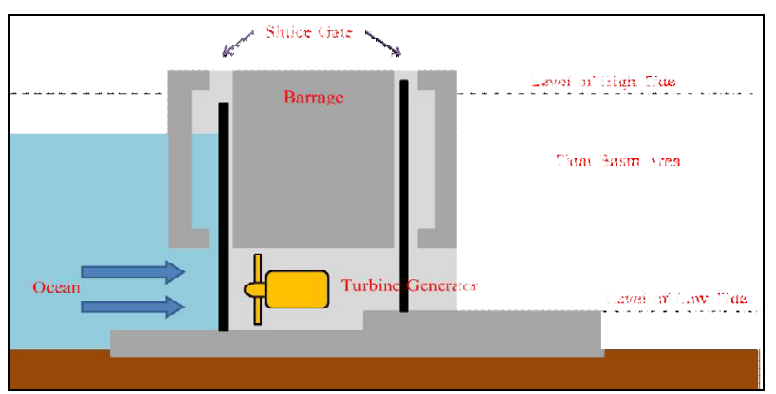

(b)

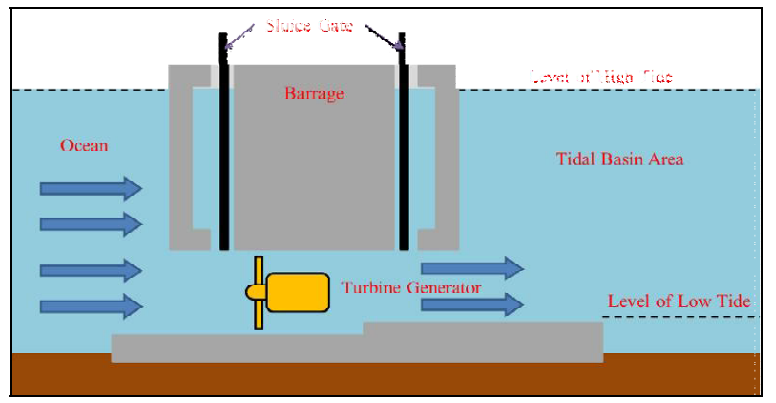

(c)

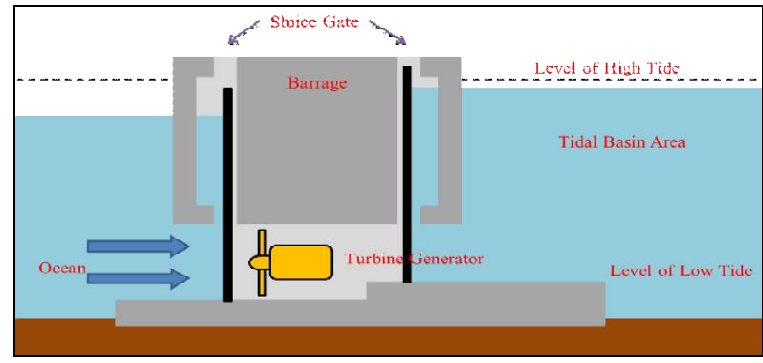

(d)

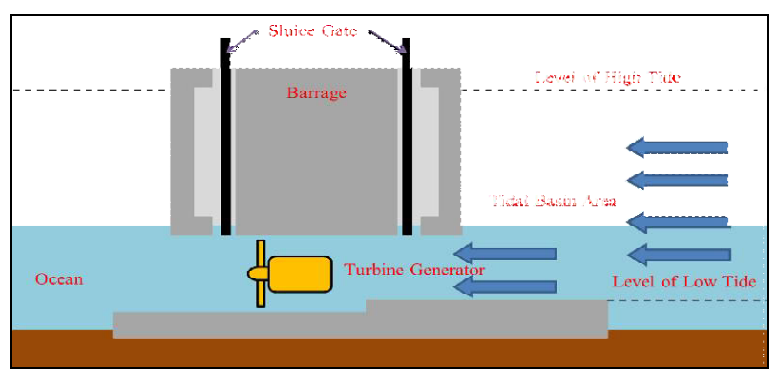

(e)

Figure 3. Double-mode generation. 


\section{Tidal range differences}

Tidal range can be defined from the tide different during the phase of flood and ebb tides. This different in height of tide can be further calculate for the tidal power generation. Figure 4 shows the average of tidal range difference of year 2011 .

Flood Generation $=\mid$ high tides - low tides $\mid$

Ebb Generation $=\mid$ low tides - high tides $\mid$

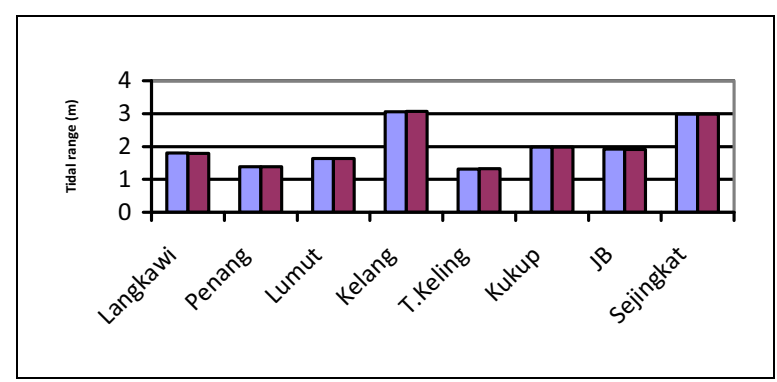

(a)

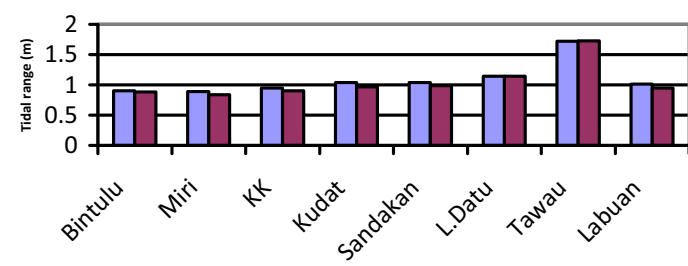

(b)

Figure 4. Tidal range differences [17, 18, 19, 20, 21].

\section{Location of tides data}

The data collected from the Department of Survey and Mapping Malaysia, shows that the highest tidal range of almost three meters is located at Sabah and Sarawak. Malaysia has 21 stations of tide gauge installation installed near to village or town. The purpose of tide gauge installation near village or town is to avoid and give warning if there is a change in increasing water level as usual that may cause flood to the nearest region. Since the tide gauge located near and at the coastal area, there will be advantage to make analysis of tidal range at nearest location of tide gauge station.

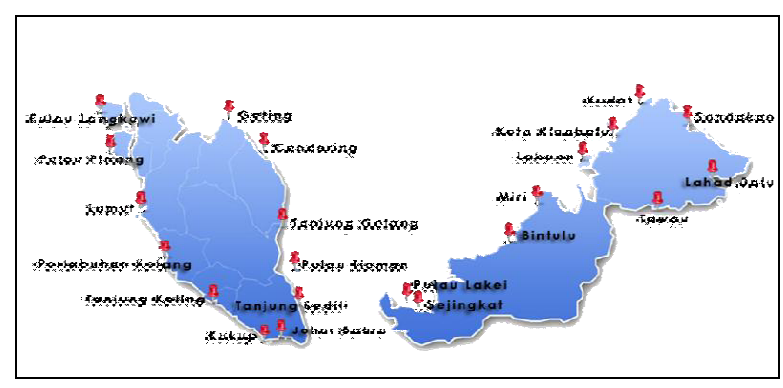

Figure 5. Tide stations of Malaysia region [17, 18, 19, 20, 21].

\section{Potential Generations}

\subsection{Gross energy potential}

A tidal barrage is capable of generation electricity power by utilizing potential power of tides. The calculation of tidal basin single action gross energy potential, $E_{f}(J)$ is calculated using following equations.

$$
\begin{aligned}
& E_{F}=\rho g \int_{z=0}^{z=R} z A_{z} d z \\
& E_{f}-\Lambda_{z} \rho g \int_{z=0}^{z=R} z d z \\
& E_{f}=A_{z} \rho g \frac{R^{2}}{2}
\end{aligned}
$$

Where $A_{z}$ is basin area $\left(\mathrm{km}^{2}\right), \rho$ is sea water density $\left(\mathrm{kg} / \mathrm{m}^{3}\right), g$ is gravitational acceleration $\left(\mathrm{m} / \mathrm{s}^{2}\right)$ and $R$ is range differences $(\mathrm{m})$.

\subsection{Gross power potential}

Since most of the tidal stations in the coastal area region of Malaysia are having mixed-tide, the number of tide in every month fluctuates. Thus, an average time of a tide is used for future equations. The average time of one tide is calculated as follow.

$$
T_{\text {tude }}-\frac{\text { time in cne month }}{N}
$$

Where $N$ is the number of tide in one month and time in one month was calculated in second. The generation time of single action power generation is as follow.

$$
T_{\text {gen }}=T_{2}^{T_{\text {tids }}}
$$

For double action power generation, the generation time is multiplied by two.

The gross power potential per tide is calculated by dividing gross energy potential with generation time in second as shown below.

$$
P_{\text {tids }}=\frac{E_{r}}{T_{\text {tids }}}
$$

Thus, the gross power potential in month is calculated by multiplying gross power potential per tide with number of tide in one month and barrage efficiency, $\eta_{\text {barrage }}$ as in equations below.

$$
P_{\text {total }}=P_{\text {tide }} \times N \times \eta_{\text {burrago }}
$$

The efficiency of a tidal barrage is commonly in the range of $20 \%$ to $40 \%$. For single action power generation, the barrage efficiency is assumed to be $40 \%$ while for double action power generation, the efficiency is assumed 
to be $30 \%$ due to lower efficiency of bi-directional turbine. Hence, the monthly power generation is calculated as follow.

$$
P_{\text {electricity }}=P_{\text {tota! }} \times N \times \frac{\tau_{\text {gुm }}}{3600}
$$

\section{Results and Discussion}

\subsection{Local electricity demand}

Firstly, before proceeding with calculation of power generation, the number of household and electricity demand for local area is identified. Table 2 shows, the number of population and electricity demand for the selected area. The average electricity consumption in Malaysia is assumed $3966 \mathrm{kWh}$ per household.

Table 2. Local electricity demand

\begin{tabular}{llrr}
\hline Location & \multicolumn{1}{c}{ Mukim } & $\begin{array}{c}\text { No. of } \\
\text { household }\end{array}$ & \multicolumn{1}{c}{$\begin{array}{c}\text { Demand } \\
\text { (GWh) }\end{array}$} \\
\hline P.Langkawi & P.Langkawi & 26,000 & 103.12 \\
P.Pinang & Georgetown & 64,653 & 256.41 \\
Lumut & Lumut & 16,591 & 65.80 \\
P.Kelang & Bandar & 3,447 & 13.67 \\
Tg. Keling & Tg. Keling & 2,991 & 11.86 \\
Kukup & Serkat & 1,976 & 7.84 \\
J.Bahru & Sg. Tiram & 3,703 & 14.69 \\
Sejingkat & Padawan & 6,636 & 26.32 \\
Bintulu & Sebauh & 35,274 & 139.90 \\
Miri & Sibuti & 11,958 & 47.43 \\
K.Kinabalu & Tambunan & 81,747 & 324.21 \\
Kudat & Pitas & 16,745 & 66.41 \\
Sandakan & Tongod & 64,194 & 254.60 \\
Lahad Datu & Kunak & 34,179 & 135.55 \\
Tawau & Nabawan & 69,656 & 276.26 \\
Labuan & W.P.Labuan & 19,719 & 78.21 \\
\hline
\end{tabular}

\subsection{Tidal basin area power generation}

Figure 6 shows the local demand for electricity and power generation from tidal barrage by using doublemode of generation. From the figure, it is shown that by using double-mode generation it can at least satisfy the electricity demand from the local usage compare to by using ebb-mode generation and flood-mode generation.

Double-mode generation can produce the higher output power generation because of the way it operates.
The operation is combinational of the ebb-mode generation and flood-mode generation, from this the operations it is almost a continuous proses if compare to the ebb-mode generation and flood-mode generation that are only operate at one time of tides process which are during ebbs and floods.

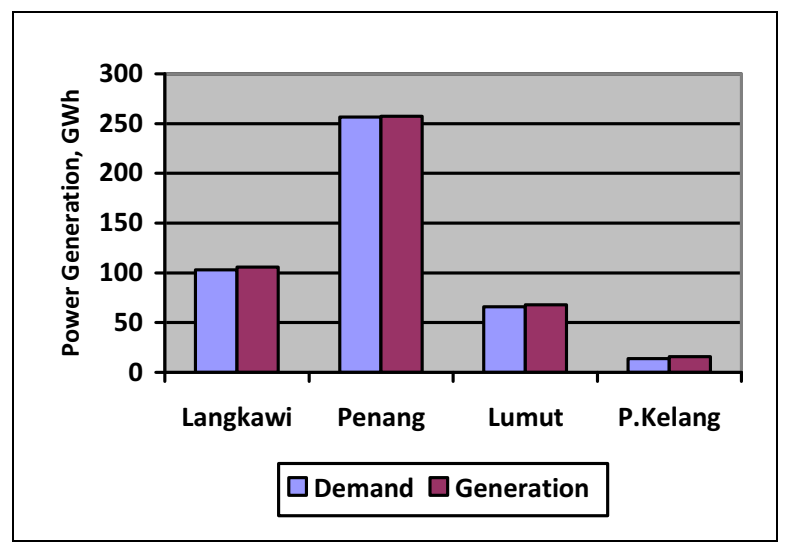

(a)

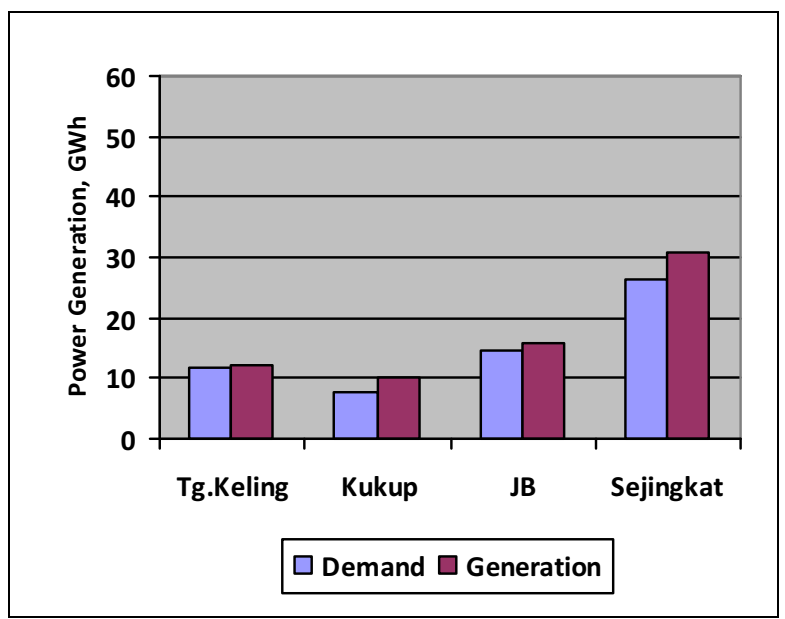

(b)

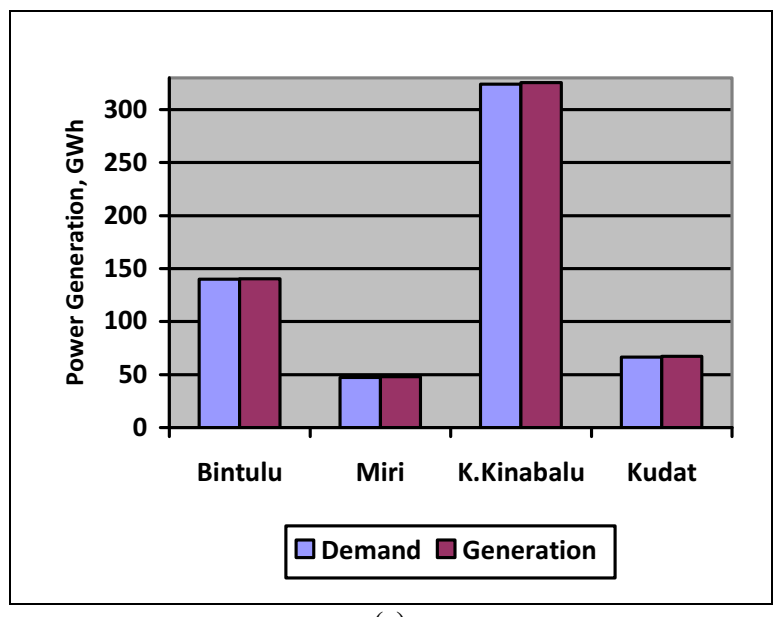

(c) 


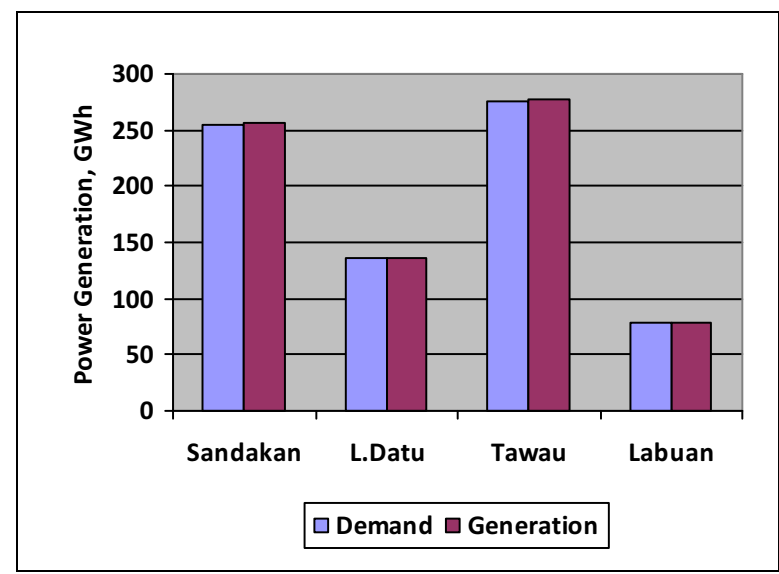

(d)

Figure 6. Demand and Power generation

\subsection{Basin area estimation}

The tidal basin area was estimated to approximate the generation of electricity to meet demand of local community per person. Thus, the tidal basin area was manipulated at each tidal station location to generate electricity to satisfy the local community electric demand. The basin area estimation for each location is shown in Table 3 below.

Table 3. Basin area estimation.

\begin{tabular}{llc}
\hline \multicolumn{1}{c}{ Location } & \multicolumn{1}{c}{ Mukim } & Basin area, $\mathbf{k m}^{2}$ \\
\hline P.Langkawi & P.Langkawi & 3.7 \\
P.Pinang & Georgetown & 15.3 \\
Lumut & Lumut & 2.9 \\
P.Kelang & Bandar Kelang & 0.2 \\
Tg. Keling & Tg. Keling & 0.8 \\
Kukup & Serkat & 0.3 \\
J.Bahru & Sg. Tiram & 0.5 \\
Sejingkat & Padawan & 0.3 \\
Bintulu & Sebauh & 13.8 \\
Miri & Sibuti & 5.7 \\
K.Kinabalu & Tambunan & 35.2 \\
Kudat & Pitas & 6.3 \\
Sandakan & Tongod & 25.3 \\
Lahad Datu & Kunak & 11.8 \\
Tawau & Nabawan & 10.4 \\
Labuan & W.P.Labuan & 7.7 \\
\hline & & \\
\hline
\end{tabular}

Figure 7 also shows the comparison of power generation between ebb-mode, flood-mode and doublemode of generation. As shown, the double modegeneration produced more power than ebb-mode and flood-mode because the double-mode generation operation is combination of ebb-mode and flood-mode generation. It can increase the power generation around $67 \%$ from the single-mode generation.

However, power generation is depending on the tides range difference and tidal basin area. These two parameters are perpendicular to the power generation. The biggest tides range difference and tidal basin area is large, so the output power generation becomes greater and vice versa.

In Malaysia, the tidal range not so high as the minimum requirement so it needs the large of tidal basin area to produce the greatest of output power generation. From the Figure 6, it shows the relation between tidal range difference and tidal basin area that how much the output power can be generated in order to meet the local demand requirement for electricity.

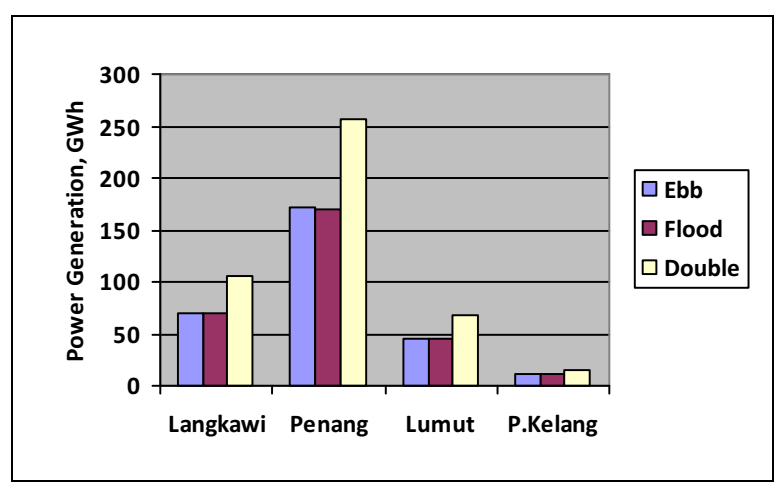

(a)

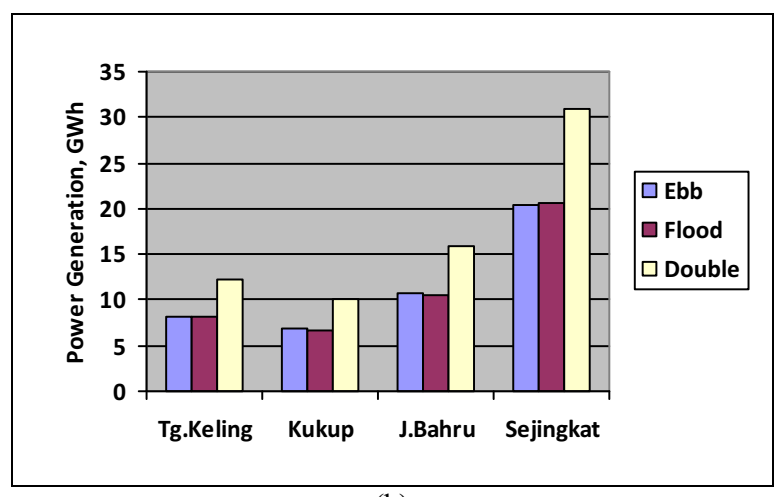

(b) 


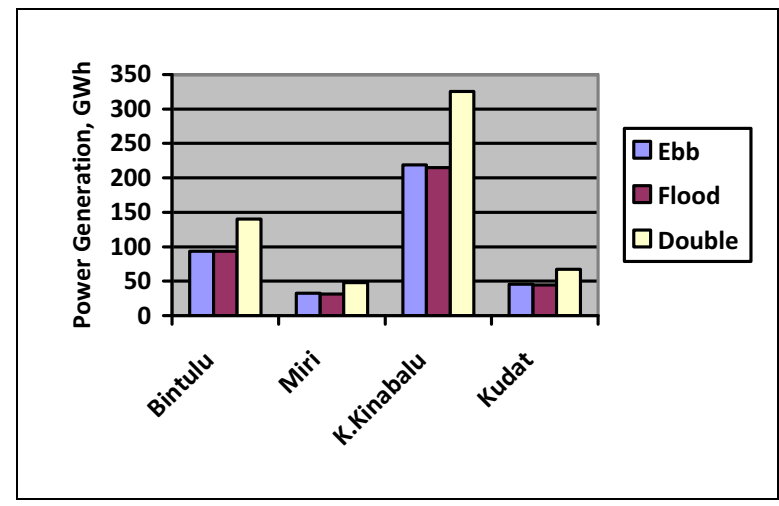

(c)

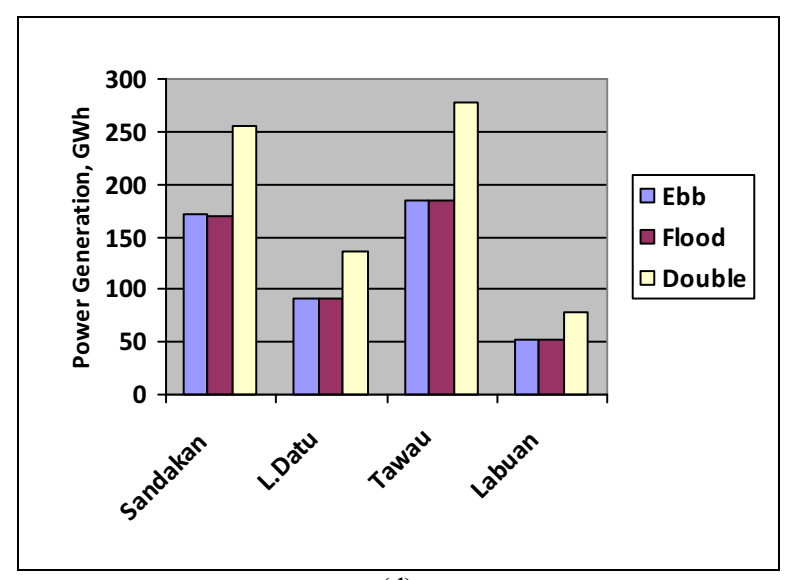

(d)

Figure 7. Power generation for ebb-mode, flood-mode and double-mode

The basin area also effected by the value of tidal range difference, which mean if the tidal range difference is too low it is require a large tidal basin area and vice versa.

A small tidal barrage is more desirable as it needs less monetary and more manageable than large tidal barrage.

\section{Conclusions}

In this paper, it was attempted to study the potential of harnessing tidal energy for electricity generation in order to satisfy the local demand. Three modes of generations which are ebb-mode generation, flood-mode generation and double-mode generation is studied and the result showed that double-mode generation can produce the power generation that can meet the local demand. However, the tidal range become one the challenges since tides Malaysia doesn't meet the minimum tides requirement for tidal barrage and other solution or method for increasing the water level need to be studied.

\section{Acknowledgements}

The authors wish to express their gratitude to the Ministry of education for supporting the research under University Research Grant RDU130620 and providing the research facilities.

\section{References}

1. K.S. Lee, L.Y.S., Simulation Studies on the Electrical Power Potential Harnessed by Tidal Current Turbines. 2009.

2. Ali, R., I. Daut, and S. Taib, A review on existing and future energy sources for electrical power generation in Malaysia. Renewable and Sustainable Energy Reviews, 2012. 16(6): p. 4047-4055.

3. BP Statistical Review of World Energy June 2014. 2014.

4. APEC ENERGY DEMAND AND SUPPLY OUTLOOK 2006, in PROJECTIONS TO 2030 ECONOMY REVIEW. 2006, ASIA PACIFIC ENERGY RESEARCH CENTRE: Institute of Energy Economics, Japan.

5. Shafie, S.M., et al., A review on electricity generation based on biomass residue in Malaysia. Renewable and Sustainable Energy Reviews, 2012. 16(8): p. 5879-5889.

6. K.S. Lee, L.Y.S., Preliminary Investigation of the Potential of Harnessing Tidal Energy for Electricity Generation in Malaysia. 2008.

7. Chen, L. and W.-H. Lam, A review of survivability and remedial actions of tidal current turbines. Renewable and Sustainable Energy Reviews, 2015. 43: p. 891-900.

8. Masayuki Kamimoto, L.M., John Nyboer, Kevin Urama, Tony Weir, Renewable Energy and Climate Change, J.P.a.J.-P.v. Ypersele, Editor. 2011.

9. Hanafi, A.S., DESALINATION USING TIDAL ENERGY, in Encyclopedia of Desalination and Water Resources (DESWARE).

10. Taburan Penduduk dan Ciri-ciri Asas Demografi, J.P. Malaysia, Editor. 2010.

11. Malaysia Energy Statistic, S. Tenaga, Editor. 2014, Suruhanjaya Tenaga.

12. S.Bhargav reddy, B.A.K., Best Non Conventional Way of Generating Electrical Power by Using Tidal Energy. International Journal of Engineering Trends and Technology (IJETT), 2013. 4(5).

13. Salequzzaman, M., Prospects and Sustainability of Green Power: Case Study of Tidal Power.

14. Meisen, P., OCEAN ENERGY TECHNOLOGIES for RENEWABLE ENERGY GENERATION. 2009.

15. Shaikh Md. Rubayiat Tousif, S.M.B.T., Tidal Power: An Effective Method of Generating Power. International Journal of Scientific \& Engineering Research, 2011. 2(5).

16. Ahmad Etemadi, Y.E., Orang AsefAfshar, Arash Emdadi, Electricity Generation by the Tidal Barrages. Energy Procedia, 2011.

17. Department of Survey and Mapping Malaysia. Rekod Cerapan Air Pasang Surut 2007.

18. Department of Survey and Mapping Malaysia. Rekod Cerapan Air Pasang Surut 2008.

19. Department of Survey and Mapping Malaysia. Rekod Cerapan Air Pasang Surut 2009. 
20. Department of Survey and Mapping Malaysia.

Rekod Cerapan Air Pasang Surut 2010.

21. Department of Survey and Mapping Malaysia.

Rekod Cerapan Air Pasang Surut 2011. 